\title{
Characterization of starch from hot water treated and untreated anchomanes difformis rhizome
}

\author{
Abe T.O $*^{1}$ and Lajide $\mathrm{L}^{2}$ \\ Department of Chemistry, Federal University of Technology, Akure, Ondo State, Nigeria
}

\begin{abstract}
Starches were prepared from Forest anchomanes' rhizome by Sedimentation method. Forest anchomanes (Anchomanes difformis) is herbaceous plants with prickly stem having huge divided leaf occurring in the forest of West Africa. One part (treated) steeped in hot water $\left(80^{\circ} \mathrm{C}\right)$ and the other part in cold water (untreated) yield $18 \%$ and $16 \%$ respectively. The starches obtained were slightly off white with true density of 1.58 and 1.54; percentage solubility at $85^{\circ} \mathrm{C}$ were 17.05 and 28.27 while swelling power were 31.42 and 40.25 ; water absorption capacity were $13 \%$ and $14.67 \%$ for hot water and cold water respectively. The proximate analysis of treated and untreated sample (\%) was found to be: fat (3.3 and 2.3), ash(1.0), crude fibre(0.4), protein(1.3 and 1.5), moisture(5.6 and 5.8), and carbohydrates 88.1 and 88.9$)$ respectively. Phytochemical composition $(\mathrm{mg} / 100 \mathrm{~g})$ of the starch revealed the presence, saponins (11.76 and 5.36), phytates (0.1 and 0.08), tannins (1.0 and 1.3), oxalates (1.97 and 1.94), cyanides (0.01), flavonoid (0.84 and 0.56), alkaloids (1.40 and 2, 79) and cardiac glycosides (0.48 and 0.55). While the peak viscosity $(B U)$ was 254.17 and 245.75 , pasting temperature $\left({ }^{\circ} C\right)$ was 81.65 and 82.46 from treated and untreated respectively. The photomicrograph indicates that the starch granule is generally small sized, not distinct but clustered with size ranging between 0.5-10 $\mu \mathrm{m}$ which is a reflection of the parent source. The starches from untreated sample have smaller granule size and higher peak viscosity than treated one. The flours (treated and untreated) analysis show that proximate composition is least affected by steeping in hot water but reduced the toxicity level and enhance the availability of minerals composition. Generally, the values obtained from the physicochemical characterization of A. difformis starch show that it has high potential for industrial applications especially in the food, textile and pharmaceutical industries.
\end{abstract}

Keywords: Anchomanes difformis, steeped, physicochemical, phytochemical, starch, photomicrograph.

\section{Introduction}

Starch is one of the most abundant substances in nature and is a renewable resource. It is a semi- crystalline carbohydrate synthesized as rough spherical granules in many plant tissues including roots, tubers, rhizomes and seeds. The major botanical sources of starch are wheat, maize, potato, cassava and taro (Tester et al., 2004). Starch is a basis of our food and industrial economy. Although it is mainly used as food, it can also be readily converted chemically and biologically into many useful and diverse products such as paper, textiles, adhesives, beverages, confectionery, pharmaceuticals, and plastics.

The conversion of starch into biodegradable plastics is being researched on by many countries. This is being achieved either by chemically modifying the starches or by blending them with other polymers (Parra et al., 2004). In both case, it is important to know the chemical as well as physical characteristics of the starch. While various attempts have been made to characterize starches derived from cassava (Sriroth et al. 1999) and taro (Moorthy.1991), little information of such studies have been reported on forest anchomanes. Anchomanes difformis is a member of Araceae family (Burkill, 1985), an herbaceous plant with prickly stem having huge divided leaf and spathe that arise from a horizontal rhizome occurring in the forest of West Africa. It is sometimes called forest Anchomanes in English (Oyetayo, 2007), while in Southwest Nigeria (Yoruba) it is known as Abirisoko, Ogirisako and Igo (Soladoye et al., 2005). The rhizome is eaten but only after special preparation that entails prolonged washing and cooking of early shooting stage (Oyetayo, 2007)The rhizomes could be vertical or horizontal, creeping at or near surface, sometimes branched; corms underground and starchy (Bown and Deni, 2000).

In the present study, starch was extracted from treated forest anchomanes rhizome (steeped in hot water at $80^{\circ} \mathrm{C}$ for $4 \mathrm{~h}$ ) and (steeped in cold water at $25^{\circ} \mathrm{C}$ for $4 \mathrm{~h}$ ) untreated. The physicochemical, phytochemical level and rheological properties of starches were determined in other to compares with other raw materials. Therefore, the aim of the research project is to explore the possibility of starch from A. difformis as a potentially useful raw material. 


\subsection{Materials}

\section{Experimental details}

Freshly harvested A. difformis rhizome, grown naturally in West African climatic and agronomic conditions, was collected from Ipinsa, Akure South local Government. Nigeria. The Sampling locations and geographical references of sampling points taken with a Global Positioning System (Garmin GPS 12 model) (N $07^{0}$ $1^{1} 145^{11}$ and $\mathrm{E} 005^{0} 08^{1} 45.8^{11}$ ) was authenticate at Crop and Pest management, Federal University of Technology, Akure.

\subsection{Dry matter content}

Flour extraction was conducted by modified procedure (Alves et al, 2002).One hundred grams of freshly washed, peeled and shredded undamaged rhizome were placed in weighed petri dishes. The samples were dried at $65^{\circ} \mathrm{C}$ for $72 \mathrm{~h}$, cooled in a desiccator and weighed immediately. The drying and weighing steps were repeated until consecutive constant weights were achieved. These steps were carried out within $24 \mathrm{~h}$ after harvest to avoid postharvest changes through physiological deterioration or moisture loss of the rhizome. Dry matter (DM) contents of the rhizome were calculated after repeated dry to constant weights.

\subsection{Preparation of starch}

Starch extraction was conducted following modified procedure of Alves et al (2002).Fresh rhizome were washed, peeled, chopped into approximately $1 \mathrm{~cm}$ cubes, these was divided into two part with one part steep in hot water $\left(80^{\circ} \mathrm{C}\right)$ for $4 \mathrm{~h}$ (treated) and the other untreated(steeped in cold water at $25^{\circ} \mathrm{C}$ for $4 \mathrm{~h}$ )and then pulverized in a high-speed blender for $5 \mathrm{~min}$. The pulp was suspended in ten times its volume of water, stirred for $5 \mathrm{~min}$. The resulting slurry was left to stand overnight at $4^{\circ} \mathrm{C}$ and then centrifuged $(5,000 \mathrm{rpm} ; 20 \mathrm{~min})$. After this, the supernatant was discarded and the colored layer manually scraped off of the starch. This centrifugation step was repeated until the supernatant layer was almost colorless. After the last centrifugation, the supernatant was decanted and toluene was added to the remaining sediment (starch). This was followed by addition of deionized water to wash the pellets until their $\mathrm{pH}$ was neutral. The recovered starch was dried using an air oven at $\sim 40^{\circ} \mathrm{C}$ for $24 \mathrm{~h}$, ground, sieved using a $425 \mu \mathrm{m}$ sieve. The yield of starch based on dry mater was determined before stored in an air tight container under dry conditions (Alves et al., 2002).

\subsection{Proximate analysis}

Moisture, protein, fat, ash, crude fibre and carbohydrates were determined from each of the flour (treated and untreated) and their starch according to A.O.A.C. (1990).

\subsection{Determination of $\mathbf{p H}$}

Five grams of the forest anchomanes flours and starches was weighed and added to $20 \mathrm{ml}$ of water in a volumetric flask. The mixture was shaken for $3 \mathrm{~min}$ and then filtered using a filter paper. The filtrate was then tested for acidity and alkalinity using a pH meter (Jenway3505 pH meter).

\subsection{Functional properties}

\subsubsection{Determination of physico-chemical properties}

Bulk and loose densities were determined by Narayara and Narasinga (1989). Bulk density was determined by placing $20 \mathrm{~g}$ of the sample into a weighed measuring cylinder and tapped gently to eliminate air spaces, the resulting volume was recorded and loose density was determined by placing $20 \mathrm{~g}$ of the sample into a measuring cylinder and the volume was recorded without tapping. Swelling capacity was determined by Leach et al. (1959) method while the procedure of Sathe et al., (1982) was used for water and oil absorption capacity. The Least Gelation Concentration (LGC) of the sample was determined using the method of Coffmann and Garciaj (1977).The procedure of Kim et al. (1995) using the Rapid Visco Analyzer (RVA) model RVA-3D was used in determining the pasting properties.

\subsubsection{Scanning electron microscopy}

A scanning electron microscope (SEM) model EVO/ MA 10 was used to determine the particle size at 100X, 500X and $1 \mathrm{KX}$ magnifications. The sample was imaged with the secondary electron detector at an accelerating voltage of $20 \mathrm{kV}$, probe current of $200 \mathrm{PA}$ and variable pressure of $50 \mathrm{~Pa}$. (Fanon et al., 1992). 


\subsection{Determination of mineral composition}

Mineral elements composition was determined using methods (A.O.A.C. 1990) recommended methods. One gram of dry sample was ashed in a furnace at $550^{\circ} \mathrm{C}$; The ashed samples were digestion with $5 \mathrm{ml}$ of $10 \%$ $\mathrm{HNO}_{3}$ prior to analysis; preparation of stock solution of the elements and the determination of the concentration of the elements using a calibration curve obtained by plotting the concentration of the pure elements against their absorbance readings from BulkScientific(210) Atomic Absorption Spectrophotometer $(\mathrm{Cd}, \mathrm{Ca}, \mathrm{Cr}, \mathrm{Cu}, \mathrm{Fe}, \mathrm{Pb}, \mathrm{Mg}$, $\mathrm{Mn}, \mathrm{Ni}, \mathrm{Zn}$ ), flame photometer ( $\mathrm{Na}$ and $\mathrm{K}$.) and of phosphorus in the starches and flours was determined by colorimetric in accordance with the approved A.O.A.C. (1990) methods.

\subsection{Determination of Phytochemicals Levels in Samples}

Spectroscopic and titrimetric methods were used to determine the levels of phytochemicals in the Forest anchomanes samples. The phytochemicals determined in the samples are total oxalates (Dye, 1956) phytates (McCance and Widdowson, 1953) and hydrogen cyanide (A.O.A.C., 1990). The others were flavonoids, saponins alkaloids (A.O.A.C., 1990), tannin (Markkar et al. 1993) and cardiac glycoside. (Gaur et al., 2009).

\subsection{Statistical Analysis}

The triplicate results were statistically analyzed using ANOVA and means were compared using least significant difference (L.S.D.) at $\mathrm{p} \leq 0.05$ levels using the Duncan Multiple Range Test from Statistical Package for Social Science (SPSS) 15.0 version (Snedecor and Cochran, 1980).

\subsection{Starch yield}

\section{Results and discussion}

A. difformis starch was isolated from freshly harvested (untreated -sample A) and hot water $\left(80^{\circ} \mathrm{C}\right)$ treated (sample B) rhizome. The starches obtained were slightly off white in colour without smell and $18 \%$ and $16 \%$ yield respectively. This yield might be an indication of appreciable accumulation of starch in the fresh rhizome, the percentage starch yield of A. difformis was similar to potato starches as reported by Parvu (1997) and higher than some un-conversional wild edible rhizome reported by Veerabahu and Chinnamadasamy (2010); Shanthakumaril et al., (2008).

\subsection{Proximate composition}

Fresh A. difformis rhizome used contains about $88 \%$ dry matter. The results of the proximate composition are presented in Table 1. Variations occurred in the proximate composition of the un- treated (sample A) and the treated (sample B) rhizome ( $\mathrm{p}<0.05)$ except for the Crude fibre and crude fat contents; these show that steeping in hot water has little effect on the proximate composition of the rhizome. The samples are less - proteinous with values about $5 \%$ for the treated and untreated sample; the result are comparable to the reported values of white yam, water yam and sweet potato (Longe, 1986; Alaise and Linden, 1999). Fiber is regarded as essential, as it absorbs water and provides roughage for the bowels, assisting intestinal transit. Very low fiber such obtained in these work; in foods is however, helpful to digestive process but it lowers the vitamin and enzyme content of the food material. This might have accounted for $10 \%$ level of A. difformis inclusion in ruminant animal concentrate diets as a safe level that will guarantee no negative effect on nutrient intake and performance (Moses et al. 2010). The carbohydrate values of $70.9-88.9 \%$ are quite reasonable as the dry matter of most root crops is made up of about $60-90 \%$ carbohydrate (Oyenuga, 1968). The values are comparable to the carbohydrate contents of white yam (Longe, 1986).

The starches from hot water treated sample (sample Bs) and un-treated (sample As) had no significant different at $\mathrm{P}<0.05$ in their proximate composition except in carbohydrate, these show that steeping in hot water has little or no effect on the proximate composition of the starch. The starches indicate less inorganic content (ash and crude fibre) as well as protain content as shown by their low value in Table 1. This was not unexpected as starches always have less inorganic (ash and crude fibre) content and the present of protein was taken as a contaminant whenever the starch meant for adhesive (Morrison, 1981). 
Characterization of starch from hot watertreated and untreated anchomanes difformisrhizome

Table1. Proximate \% composition of sample from Anchomanes difformisrhizome and its starch

\begin{tabular}{lllllll}
\hline Sample & Moisture & Ash & Crude Fat & Crud Fibre & Protein & Carbohydrate \\
\hline A & $7.54^{\mathrm{b}} \pm 0.27$ & $5.30^{\mathrm{b}} \pm 0.75$ & $4.99^{\mathrm{b}} \pm 0.02$ & $5.69^{\mathrm{b}} \pm 0.18$ & $3.40^{\mathrm{b}} \pm 0.25$ & $73.09^{\mathrm{b}} \pm 0.87$ \\
B & $8.03^{\mathrm{c}} \pm 0.08$ & $7.38^{\mathrm{c}} \pm 0.08$ & $3.07^{\mathrm{b}} \pm 0.18$ & $5.82^{\mathrm{b}} \pm 0.04$ & $5.33^{\mathrm{c}} \pm 0.01$ & $70.09^{\mathrm{a}} \pm 0.06$ \\
As & $5.63^{\mathrm{a}} \pm 0.38$ & $1.02^{\mathrm{a}} \pm 0.02$ & $3.27^{\mathrm{a}} \pm 0.23$ & $0.42^{\mathrm{a}} \pm 0.01$ & $1.33^{\mathrm{a}} \pm 0.45$ & $88.06^{\mathrm{c}} \pm 0.11$ \\
Bs & $5.81^{\mathrm{a}} \pm 0.06$ & $1.01^{\mathrm{a}} \pm 0.03$ & $2.32^{\mathrm{a}} \pm 0.17$ & $0.42^{\mathrm{a}} \pm 0.01$ & $1.48^{\mathrm{a}} \pm 0.25$ & $88.87^{\mathrm{c}} \pm 0.11$
\end{tabular}

Results are mean \pm standard deviation of triplicate determinations expressed on dry weight basis. Values along the same column with different superscripts are significantly different $(\mathrm{P}<0.05)$.

Where $\mathbf{A}=$ untreated $A$. difformis rhizome sample, $\mathbf{B}=$ treated $A$. difformis rhizome sample,

$\mathbf{A s}=$ starch from untreated A. difformis rhizome sample And $\mathbf{B s}=$ starch from treated A. difformis rhizome sample.

\subsection{Functional properties of the flours and starch}

The water absorption capacity (WAC) of difformis flour and isolated starch presented in Table 3 showed that soaking of the sample in hot water as treatment before extraction of the starch increased the water absorption capacity which agrees with the findings of Sefa-Dedeh and Agyir-sackey (2006). The values obtained are higher than sweet potatoes flour, red $24 \%$ and white $26 \%$ in the flour (Osundahunsi et al.,2003). The extent of protein hydration correlates strongly with the content of polar residues as well as the interaction between water molecules and hydrophilic groups which occurs via hydrogen bonding. The higher protein content of the treated sample might be responsible for high hydrogen bonding and high electrostatic repulsion, both conditions facilitating binding and entrapment of water (Altchul and Wilcke, 1985). Hence, WAC of the treated sample gave it an advantage of being used as a thickener in liquid and semi-liquids foods since the flour and its starch has the ability to absorb water and swell for improved consistency in food.

Table2. Functional properties of the samples

\begin{tabular}{|c|c|c|c|c|c|c|c|c|c|}
\hline Sample & WAC $\%$ & $\mathrm{OAC} \%$ & $\begin{array}{l}\text { Loose bulk } \\
\text { density }\end{array}$ & $\begin{array}{l}\text { Pack-bulk } \\
\text { density }\end{array}$ & True density & $\begin{array}{l}\text { Gelation } \\
\text { strength } \%\end{array}$ & $\mathrm{pH}$ & Swelling power & Solubility \\
\hline$A$ & $\begin{array}{l}31.00^{3}=0.0 \\
0\end{array}$ & $28.17^{6}=0.29$ & $0.58^{2}=0.02$ & $0.63=0.02$ & $1.39^{2}=0.02$ & $\begin{array}{l}17.33^{2}=0.5 \\
8\end{array}$ & $5.74^{2}=0.02$ & $41.03^{b}=0.03$ & $23.25^{6}=0.03$ \\
\hline B & $\begin{array}{l}32.00=0.1 . \\
0\end{array}$ & $24.00=0.00$ & $0.50^{6}=0.00$ & $0.53^{b}=0.01$ & $1.45^{2}=0.02$ & $\begin{array}{l}17.33=0.5 \\
8\end{array}$ & $5.60^{2 b}=0.01$ & $59.91=0.14$ & $17.11=0.02$ \\
\hline $\mathrm{AS}$ & $\begin{array}{l}13.33^{\circ}= \\
1.16\end{array}$ & $30.00=0.00$ & $0.69^{b}=0.03$ & $0.77^{6}=0.02$ & $1.54^{6} \pm 0.02$ & $\begin{array}{l}10.33^{6}=0.5 \\
8\end{array}$ & $6.14^{6}=0.02$ & $31.42=0.21$ & $17.05=0.12$ \\
\hline
\end{tabular}

Results are mean \pm standard deviation of triplicate determinations expressed on dry weight basis. Values along the same column with different superscripts are significantly different $(\mathrm{P}<0.05)$.

Where $\mathbf{A}=$ untreated $A$. difformis rhizome sample, $\mathbf{B}=$ treated $A$. difformis rhizome sample,

$\mathbf{A s}=$ starch from untreated $A$. difformis rhizome sample And $\mathbf{B s}=$ starch from treated A. difformis rhizome sample

\subsection{Mineral content of the flours and starch}

The mineral analysis result in table. 3 reveals that the rhizome of A. difformis appears to be rich sources of potassium when compared with the Recommended Dietary Allowances (RDA) of NRC/NAS (1989) for infants and children. Robinson (1987) reported that a diet that meets two thirds of the Recommended Dietary Allowances (RDA) values is considered to be adequate for an individual. The high content of Potassium can be utilized beneficially in diets of people who take diuretics to control hypertension and suffer from excretion of potassium through the body fluid (Siddhuraju et al., 2001) well-cooked of earlier shoot had been recommended for human consumption (Oyetayo, 2007) The calcium and Iron content in the rhizome of A. difformis is found to be higher than an earlier study in the corms of Colocasia esculenta and Alocasiam acrorrhiza( Aggarwal et al. 1999); tubers of Dioscorea spp. (Rajyalakshmi and Geervani, 1994; Shanthakumariet al.,2008; Murugesan and Ananthalakshmi, 1991). Iron content was higher compared to infants, children and adults RDA's of NRC/NAS (1980). The copper content, in the Anchomanes difformis appears to be lower when compared with the other wild yam as reported by 
Shanthakumari et al. (2008). Cadmium, Chromium, Lead and Nickel were not present in both rhizome and starch of forest Anchomanes.

Steeping has significant effect on antinutrients as show by phytate and cyanide . it had been reported that physical and chemical process such as soaking, cooking germination, fermentation, selective extraction and enzyme treatment are capable of reduce antinutrients content in food. (Friedman et al., 2003; González et al., 2002). Cyanide content in these research falls below the lethal dose of free HCN for an adult; that is $50-60 \mathrm{mg} / 100 \mathrm{~g}$ but the toxicity of bound $\mathrm{HCN}$ is less clearly understood.

Table 3 Minerals composition ( $\mathrm{mg} / \mathrm{kg}$ ) of sample from Anchomanes difformis rhizome

\begin{tabular}{|c|c|c|c|c|c|c|c|c|c|c|c|c|c|c|}
\hline Sample & $\mathrm{Ca}$ & $\mathrm{Mg}$ & $\mathrm{Fe}$ & $\mathrm{Mn}$ & $\mathrm{Cu}$ & $\mathrm{Zn}$ & $\mathrm{Cd}$ & $\mathrm{Cr}$ & $\mathrm{Pb}$ & $\mathrm{Ni}$ & $\mathrm{Na}$ & $\mathrm{K}$ & Sulphate & Phosphorus \\
\hline A & $\begin{array}{l}3519.2 \\
=4.8\end{array}$ & $\begin{array}{l}1981.76^{2} \\
=0.6\end{array}$ & $\begin{array}{l}133.48^{2} \\
=1.3\end{array}$ & $\begin{array}{l}39.52^{\mathrm{a}} \\
\pm 0.4\end{array}$ & $\begin{array}{l}11.63^{6} \\
\pm 3\end{array}$ & $\begin{array}{l}18.46^{\circ} \\
=0.5\end{array}$ & $\mathrm{Nd}$ & $\mathrm{Nd}$ & $\mathrm{Nd}$ & $\mathrm{Nd}$ & $\begin{array}{l}1729.69^{\circ} \\
=0.9\end{array}$ & $\begin{array}{l}4185.93^{\circ} \\
=0.7\end{array}$ & $\begin{array}{l}72.29 \mathrm{a} \\
\pm 0.4\end{array}$ & $\begin{array}{l}100.48^{\circ} \\
\pm 0.5\end{array}$ \\
\hline B & $\begin{array}{l}3237.2 \\
b=6.9\end{array}$ & $\begin{array}{l}868.98^{6} \\
=2.6\end{array}$ & $\begin{array}{l}133.51^{2} \\
=1.1\end{array}$ & $\begin{array}{l}10.39^{6} \\
\pm 0.5\end{array}$ & $\begin{array}{l}3.62^{2} \\
=0.7\end{array}$ & $\begin{array}{l}29.34^{d} \\
=0.5\end{array}$ & $\mathrm{Nd}$ & $\mathrm{Nd}$ & $\mathrm{Nd}$ & $\mathrm{Nd}$ & $\begin{array}{l}2426.56^{2} \\
=1.0\end{array}$ & $\begin{array}{l}6113.22^{2} \\
=0.0\end{array}$ & $\begin{array}{l}50.51^{\mathrm{c}} \\
\pm 0.4\end{array}$ & $\begin{array}{l}54.61^{\mathrm{c}} \\
\pm 0.2\end{array}$ \\
\hline As & $\begin{array}{l}428.65 \\
=2.5\end{array}$ & $\begin{array}{l}68.96^{\mathrm{d}} \\
=1.0\end{array}$ & $\begin{array}{l}16.0^{6} \\
=0.0\end{array}$ & $\begin{array}{l}35.16^{\mathrm{c}} \\
=0.6\end{array}$ & $\begin{array}{l}8.37^{6-} \\
=0.0\end{array}$ & $\begin{array}{l}5.82^{2} \\
=0.1\end{array}$ & $\mathrm{Nd}$ & $\mathrm{Nd}$ & $\mathrm{Nd}$ & $\mathrm{Nd}$ & $\begin{array}{l}287.33^{\mathrm{d}} \\
=4.0\end{array}$ & $\begin{array}{l}310.29^{d} \\
=0.6\end{array}$ & $\begin{array}{l}61.08^{b^{-}} \\
=0.9\end{array}$ & $\begin{array}{l}112.80^{2} \\
=0.1\end{array}$ \\
\hline Bs & $\begin{array}{l}941.09 \\
=1.9\end{array}$ & $\begin{array}{l}73.48^{6} \\
=0.3\end{array}$ & $\begin{array}{l}11.47^{6} \\
=0.3\end{array}$ & $\begin{array}{l}6.94^{2} \\
=0.1\end{array}$ & $\begin{array}{l}3.56^{2} \\
=0.1\end{array}$ & $\begin{array}{l}23.87^{6} \\
=0.1\end{array}$ & $\mathrm{Nd}$ & $\mathrm{Nd}$ & $\mathrm{Nd}$ & $\mathrm{Nd}$ & $\begin{array}{l}827.33^{\mathrm{G}} \\
=1.9\end{array}$ & $\begin{array}{l}717.64^{6} \\
\pm 5.1\end{array}$ & $\begin{array}{l}61.08^{6} \\
=0.9\end{array}$ & $\begin{array}{l}57.94^{6} \\
=1.0\end{array}$ \\
\hline
\end{tabular}

Results are mean \pm standard deviation of triplicate determinations expressed on dry weight basis. Values along the same column with differen superscripts are significantly different $(\mathrm{P}<0.05)$.

Where $\mathbf{A}=$ untreated $A$. difformis rhizome sample, $\mathbf{B}=$ treated A. difformis rhizome sample, As = starch from untreated A. difformis rhizome sample And $\mathbf{B s}=$ starch from treated A. difformis rhizome sample. $\mathrm{Nd}=$ not detected

\subsection{Phytochemical properties of $A$. difformis}

The glycosides are hydrolysed to $\mathrm{HCN}$ by the endogenous enzyme linamarase, which is present in the human digestive tract. All the traditional food processing methods reduce or remove the toxicity by releasing $\mathrm{HCN}$ from the glycosides. Since $\mathrm{HCN}$ is soluble in water and has a boiling point of $25^{\circ} \mathrm{C}$ it can be removed by soaking.

Tannin content are between $1.00-1.67 \mathrm{~g} / 100 \mathrm{~g}$ which is higher than Dioscorea spp (Shanthakumari et al., 2008). Recent reports show that tannins may have potential value as cytotoxic and/or antineoplastic agents (Aguinaldo et al., 2005) Improved ferment ability of meal nitrogen in the rumen has also been reported by Mathieu and Jouany (1993). while low dosages tannin (0.15-0.2 \%) in the diet can be beneficial because it have positive effects on silage quality in the round bale silages, in particular, reducing NPNs (non -protein nitrogen) in the lowest wilting level (Tabacco et al., 2006) aside from the use of tannins as antimicrobial agents or prevention of dental caries; they are

Table 4. Phytochemical level of samples from Anchomanes difformis rhizome (mg/100g)

\begin{tabular}{|c|c|c|c|c|c|c|c|c|}
\hline $\begin{array}{l}\text { Parameter/ } \\
\text { Sample }\end{array}$ & Phytate & Tannin & $\begin{array}{l}\text { Oxalate } \\
\text { content }\end{array}$ & $\begin{array}{l}\text { Cyanicle } \\
\text { content }\end{array}$ & $\begin{array}{l}\text { Cardiac } \\
\text { Glycoside }\end{array}$ & Flavonoid & Alkaloid & Saponin \\
\hline A & $0.40^{b}=0.01$ & $1.67^{2}=0.06$ & $2.21^{b}=0.01$ & $0.02^{2} \pm 0.01$ & $0.10^{2}=0.07$ & $7.61=0.05$ & $15.23=0.03$ & $6.88^{b}=0.01$ \\
\hline B & $0.33^{2}=0.02$ & $1.67^{2}=0.06$ & $2.32=0.04$ & $0.01^{2}=0.01$ & $0.16^{2} \geq 0.03$ & $8.76^{\circ}=0.08$ & $19.26^{d}=0.18$ & $7.20^{\circ}=0.02$ \\
\hline As & $0.11^{c}=0.01$ & $1.00^{2}=0.00$ & $1.97^{2}=0.03$ & $0.01^{2}=0.01$ & $0.48^{b}=0.04$ & $0.84^{b}=0.03$ & $1.40^{2}=0.01$ & $11.76^{d}=0.01$ \\
\hline $\mathrm{Bs}$ & $0.08^{c}=0.01$ & $1.33^{2}=0.06$ & $1.94^{2}=0.01$ & $0.01^{2}=0.01$ & $0.55=0.12$ & $0.56^{2}=0.06$ & $2.79^{b}=0.04$ & $5.36^{2}=0.01$ \\
\hline
\end{tabular}

Results are mean \pm standard deviation of triplicate determinations expressed on dry weight basis. Values along the same column with different superscripts are significantly different $(\mathrm{P}<0.05)$.

$$
\text { www.iosrjournals.org }
$$


Where $\mathbf{A}=$ untreated $A$. difformis rhizome sample, $\mathbf{B}=$ treated $A$. difformis rhizome sample, $\mathbf{A s}=$ starch from untreated A. difformis rhizome sample And $\mathbf{B s}=$ starch from treated A. difformis rhizome sample

now being used in the manufacture of plastics, paints, ceramics and water softening agents (Bandarayanake, 2002).

The presence of tannins in all of the crude extracts examined may justify their therapeutic use as astringent (A. difformis rhizome) to cure dysentery which is mainly due to enteric infection by Oyetayo (2007). The present offlavonoids, (a large group of naturally occurring plant phenol compounds including flavones, flavonols, isoflavones, flavonones and chalcones) in forest anchomanes is of great importance since it had been known as nature's tender drugs, possess numerous biological/ pharmacological activities. Recent reports of antiviral, antifungal, antioxidant, anti-inflammatory, antiallergenic, antithrombic, anticarcenogenic, hepatoprotective, and cytotoxic activities of flavonoids have generated interest in studies of flavonoid-containing plants. Of these biological activities, the anti-inflammatory capacity of flavonoids has long been utilized in Chinese medicine and the cosmetic industry as a form of crude plant extracts (Aguinaldo et al. 2005; Moon et al, 2006; Jiang et al. 2008; Kim et al. 2004; Wu et al. 2008). The presence of flavonoids in all crude plant extracts may confirm their folkloric use in treating rheumatism Akah and Njike (1990).

\subsection{Pasting properties of starches from $A$. difformis}

The result of amylograph of starches was as show in the table 4 . The peaks time, pasting temperature are very close to each other indicating that both starches from the A. difformis rhizome were thermo-resistant with relatively opaque and less viscous gels, these was similar to the result obtained by Saahore et al (2005) for six different wide yam but higher than those obtained by Aprianita(2010) for Taro (72. 89), yam (72. 32) and Sweet potato (64. 48). Their aqueous suspensions contained less amylose and showed a slight tendency to retrogradation. Such properties are positive quality factors for the potential use of starches from these lesser known rhizome species.

Table5. Result from amylograph of A. difformis

$\begin{array}{llllllll} & \text { Peak viscosity } & \text { Trough } 1 & \text { Breakdown } & \text { Final Visc } & \text { Setback } & \text { Peak Time } & \text { Pasting Temp } \\ \text { As } & 254.17 & 245.92 & 10.75 & 377.17 & 131.25 & 4.22 & 81.65 \\ \text { Bs } & 245.75 & 216.17 & 29.58 & 327.17 & 111.00 & 4.38 & 82.46\end{array}$
rhizome sample

Where $\mathbf{A s}=$ starch from untreated A. difformis rhizome sample, $\mathbf{B s}=$ starch from treated A. difformis

\subsection{Photomicrograph of anchomanes starch at different magnifications.}

Plate 1 shows the photomicrograph of anchomanes starch at various magnifications using a scanning electron microscope. The starch granules are very small sized, haxagonal in shape and show aggregation forming lumps which is the reason why the starch suspension does not settle even when left over night. It has a particle size that ranges between $1-1.5 \mu \mathrm{m}$; this is due to the fact that a light microscope was used then as against the present work that employed a scanning electron microscope. The granule size is comparable to that of amaranth starch (Bandhari and Singhal, 2002) and such small sized starches are more reactive than starches with larger granule size (,Trubiano 1987). Generally, small and medium sized starch granules have been reported to have varied utilization in the food and pharmaceutical industries (Omojola et al., 2010) which gives credence to the industrial potentials of the starch.
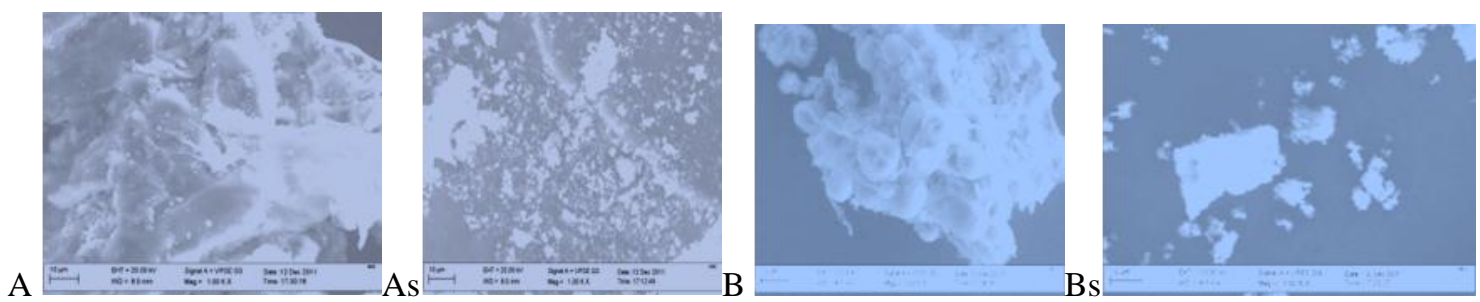

Mag : $100 \mathrm{x}$ 

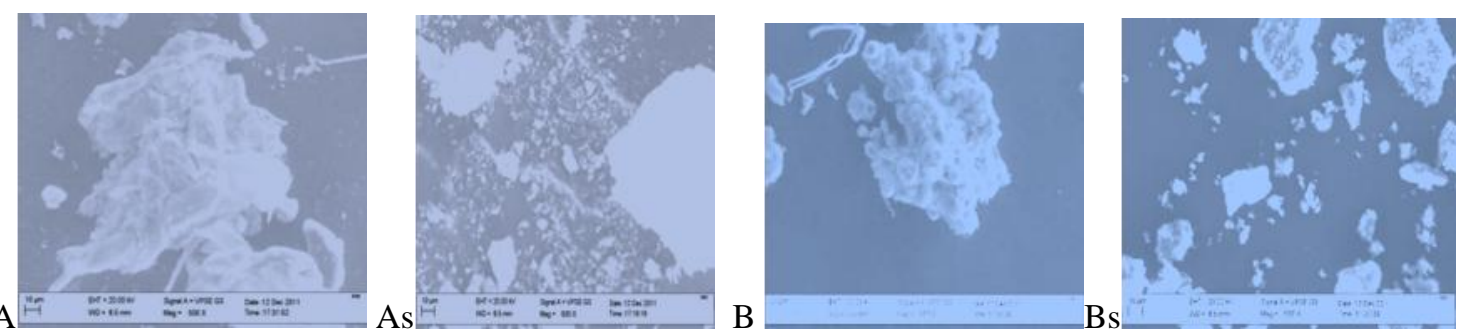

Mag: 500x
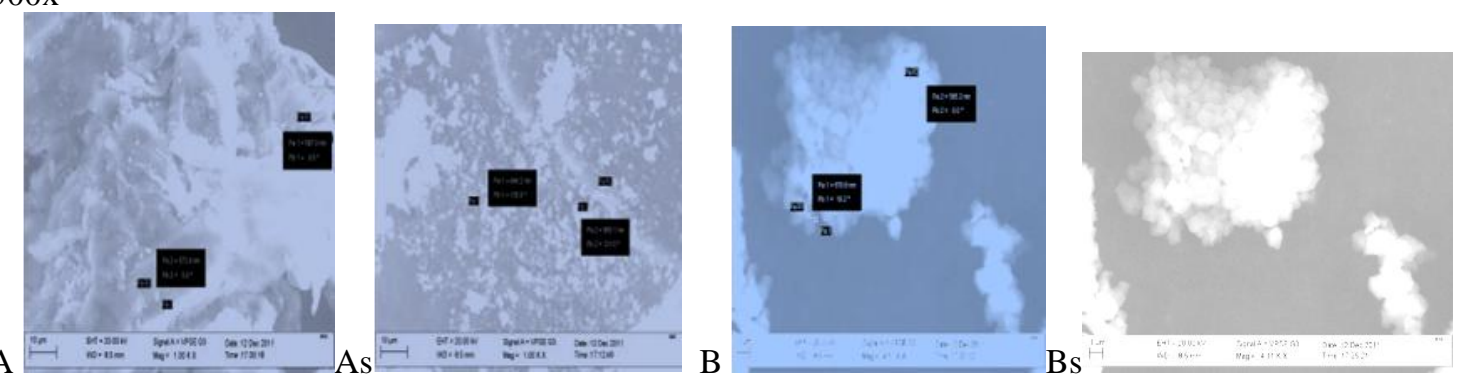

Mag: 1000x

Plate 1: Photomicrograph of anchomanes flour and their starch sample at $0.1 \mathrm{KX}, 0.5 \mathrm{KX}$ and $1 \mathrm{KX}$ respectively

Where $\mathbf{A}=$ untreated $A$. difformis rhizome sample, $\mathbf{B}=$ treated $A$. difformis rhizome sample, $\mathbf{A s}=$ starch from untreated A. difformis rhizome sample, $\mathbf{B s}=$ starch from treated A. difformis rhizome sample.

\section{Conclusion}

Some physicochemical properties of anchomanes difformis starch have been examined and these properties compare favourably with other starches. The study has therefore shown anchomanes difformis as potential source of industrial starch. This will help to reduce the burden on starch from other well-known sources such as corn, potato and cassava and make starch available at low cost; also the reduction in antinutrients as a result of the steeping in hot water enhance the nutritive value of the Anchomanes difformis flour thus could be fed by the animal.

\section{References}

[1]. Aggarwal, R.A.K., Arya, P.S. and Mahajan, N.C. (1999). Nutritional evaluation of vegetable: Colocasia. Journal of Food Science and Technology, 36: $457-458$.

[2]. Aguinaldo A.M, Espeso E.I, Guevara B.Q. and Nonato M.G (2005).Phytochemistry. In: Guevara BQ (ed.) A Guidebook to Plant Screening: Phytochemical and Biological. University of Santo Tomas, Manila, Philippines.

[3]. Akah P.A and Njike H.A. (1990) Some pharmacological effects of rhizome aqueous extract of Anchomanes difformis Fitoterapia 61. 368-370.

[4]. Alaise, C. and Linden, G. (1999). Food Biochemistry. Aspen Publishers Inc.: Baltimore, MD.

[5]. Altschul, M. and Wilcke.A.L.(1985). New protein food, Journal of Food Science and Technology, Orlando, FL. Academic Press

[6]. AOAC (1990).Association of Official Analytical Chemist; Official Methods of .15 $5^{\text {th }}$ edition. Association of Analytical Chemists, Washington D.C, U.S.A.pp. 22201-3301.

[7]. Alves, R.M., Grossmann, M.V., Ferrero, C., Zaritzky, N.E., Martino, M.N., and Sierakoski, M.R. (2002). Chemical and functional characterization of products obtained from yam tubers. Starch, 54, 476-481.

[8]. Aprianita A. (2010). Assessment of underutilized starchy roots and tubers for their applications in the food industry, a thesis submitted in fulfillment of the requirements of the degree of Master of Science, School of Biomedical and Health Sciences, Victoria University, Werribee Campus, Victoria, Australia.

[9]. Bandarayanake W..M (2002). Bioactivities, bioactive compounds and chemical constituents of mangrove plants. Wetl. 10(6): 421-452.

[10]. Bandhari P. N., Singhal R. S. (2002). Studies on the optimization of preparation of succinate derivatives from corn and amaranth starches; Carbohydrate polymers 47: 277 - 283

[11]. Bourtoom, T., Chinnan, M. S., Jantawat, P. and Sanguandeekul, R.(2009). Recoveryand characterization of proteins precipitated from surimi wash-water. Food Science andTechnology 42: 599- 605.

[12]. Bown and Deni (2000).Aroids: Plants of the Arum Family. Timber Press. ISBN 0-88192-485-487

[13]. Burkill, H.M. (1985).The Useful Plants of West Tropical AfricaAnchomanes difformis. $2^{\text {nd }}$ Edn.,pp: 196 -197.

[15]. Coffmann, C.W. and and GarciajV.V.(1977). Functional properties and amino acid content of a protein isolate from mung bean flour. Int. J. Food Sci. Technol., 12: 473-484.

[16]. Dye, W.B., 1956. Studies on Halogeton glomeratus weeds, J. of Nutri. Sci., (4): 504

[17]. Fanon, J.E., Hauber, R.J., and BeMiller, J.N. (1992). Surface pores of starch granules. Cereal Chemistry, 69. 284-288

[18]. Friedman, M., Roitman, J.N. and Kozukue, N. (2003).Glycoalcaloids and calystegine contents of eight potato cultivars, Journal of Agricultural and Food Chemistry, 51: 2964-2973.

[19]. Gaur R, Azizi M, Gan J , Hansal P, Harper, Mannan R, Panchal A, Patel K, Patel M, Patel N, González S, Pabón M.L and Carulla J. (2002)."Effects of tannins on in vitro ammonia release and dry matter degradation of soybean meal".Arch. Latinoam. Prod. Anim.10 (2): 97-101. 
[20]. Jiang H, Zhan W.Q, Liu X and Jiang S.X (2008). Antioxidant activities of extracts and flavonoid compounds from Oxytropis falcate Bunge. Nat. Prod. Res. 22(18): 1650-1656.

[21]. Kim H.P, Son K.H, Chang H.W and Kang S.S (2004).Anti-inflammatory Plant Flavonoids and Cellular Action Mechanisms. J. Phamacol. Sci. 96: $229-245$

[22]. Kim, Y.S., Wiesenborn, D.P., Orr, P.H. and Grant, L.A. (1995). Screening potato starch for novel properties using differential scanning calorimetry. J. Food Sci. 60: 1060-1065

[23]. Leach, H.W., D.L. McCowen and T.J. Schoch, 1959. Swelling and solubility patterns of various starches. Cereal Chem., 36: 534-544

[24]. Longe, O.G. (1986).“Energy Content of Some Tropical Starchy Crops”.Nigerian Agricultural Journal. 21:136

[25]. Makkar H.P.S, Blummel, M, Borony, N.K; and Becka, K (1993) Gravimetric determination of tannin and their correlations with chemical and protein precipitation methods

[26]. Mathieu F. and Jouany J.P. (1993).Effect of chestnut tannin on the fermenctability of soya bean meal nitrogen in the rumen. Ann Zootech $42,127$.

[27]. McCance, E.E. and E.M. Widdowson,(1953). Phytic acid in human nutrition. Biochem. J. (29): 2694-2999.

[28]. Moon Y.J, Wang X. and, Morris M.E (2006). Dietary flavonoids: Effects on xenobiotic and carcinogen metabolism. 20: 187-210.

[29]. Moorthy S. N (1991).Extraction of starches from tuber crops using ammonia. Carbohydrate polymers, 16: $391-398$.

[30]. Morrison, W.R. (1981). Starch lipids: A reappraisal. Starch33:408-410.

[31]. Moses A Young A, Karl-Heinz S, Oluwaseun B, Adebayo O, Peter D, Iyabo S (2010) Chemical Composition of Different Parts of Wild Yam(Anchomanes difformis) and the Nutritive Potentials of its Tuber for Inclusion in Small Ruminant Diet Tropentag, PP 14-16.

[32]. Murugasen, P.T. and Ananthalakshmi, A. (1991). Dietary practices of the Palliyar tribal group and the nutrient content of unconventional foods consumed. Indian Journal of Nutrition Dietaries. 28: 297 - 301.

[33]. Narayara, K. and NarasingaR.M.S.(1989). Effect of partial hydrolysis on winged bean (psophcocarus tetragono lobus) flour. J. Food Sci., 49: 944947.

[34]. NRC / NAS( 1980). National Research Council Committee on Dietary Allowances. Recommended Dietary Allowances 9th edn. National Academy of Science Press. Washington, DC. USA.

[35]. NRC / NAS (1989).National Research Council Committee on Dietary Allowances Recommended Dietary Allowances 10th edn. National Academy of Science Press. Washington, DC. USA.

[36]. Omojola M. O., Akinkunmi Y. O., Olufunsho K. O., Egharevba H. O. and Martins E. O. (2010): Isolation and physico-chemical characterization of cola starch; African Journal of food, agriculture, nutrition and development. 10(7): $2884-2900$

[37]. Onyenuga, V.A. (1968).Nigeria's Food and Feeding Stuffs, their Chemistry and Nutritive Value. 3rd edition. Ibadan University Press: Nigeria.

[38]. Osundahunsi, O.F., Fagbemi, T.N., Kesselman, E. and Shimoni, E.(2003) Comparison of the physicochemical properties and pasting characteristics of flour and starch from red and white sweet potato cultivars. Journal of Agricultural Food Chemistry 51: 2232-2236.

[39]. Oyetayo V. O. (2007) Comparative studies of the phytochemical and antimicrobial properties of the leaf, stem and tuber of Anchomanes difformis. Journal of Pharmacology and Toxicology 2(4): 407-410.

[40]. Parra, D.F., C.C. Tadini, P. Ponce and A.B. Lugao, (2004). Mechanical properties and water vapor transmission in some blends of cassava starch edible films. Carbohydrate Polymers, 58: 475-481.

[41]. Pârvu C. (1997) Universulplantelor.Micăenciclopedie; Ed.Enciclopedică, Bucuresti

[42]. Pearson, D., 1975. The chemical analysis of food. 7th ed. Churchill, Livingstone, Edinburgh, pp: 180-195.

[43]. Rajyalakshmi P. and Geervani P. (1994). Nutritive value of the foods cultivated and consumed by the tribals South India. Plant Foods for Human Nutrition.46: 53 -61.

[44]. RanaJ. andRogowska A. (2009). British Pharmacopoeia Volume I \& II, pp. 8734

[45]. Robinson, D.R. (1987).Food biochemistry and nutritional value. Longman Scientific and Technol,Burnmell, Haslow, England, pp 327-328

[46]. Sahoré D.A, Amani N.G. and Nemlin G.J (2005).The properties of starches from some Ivory Coast wild yam (Dioscorea) species. Tropical Science 45: $122-125$.

[47]. Sathe, S.K., Deshpande S.S. and Salunkhe, D.K. (1982). Functional properties of lupin seed (Lupirinus nutabilis) proteins and protein concentrates. J. Food Sci., 47: 491-497

[48]. Sefa-dedeh, S. and Agyir-sackey,E.K. (2006). Chemical composition and effect of processing on oxalate content of cocoyam Xanthosoma sagittifolium and Colocasia esculenta cormel.J. Food Chem., 85: 479- 487.

[49]. Shanthakumari, S. Mohan, V.R. and J. De Britto, A. (2008). Nutritional evaluation and elimination of toxic principles in wild yam (Dioscoreaspp.). Tropical and SubtropicalAgroecosystems. 8: 313-319.

[50]. Siddhuraju P., Becker K. and Makkar H.P. (2001). Studies of the nutritional composition and antinutritional factors of three different germplasm seed materials of an underutilized tropical legume, Mucunapruriensvar. utilis.Journal of Agricultural and Food Chemistry, 48, 6048-6060.

[51]. Snedecor G. W. And Cochran W.G. (1980).Statistical Methods, 7thEd.Oxford and IBI Public.Co.

[52]. Sriroth, K. Santisopasri, C. Petchalanuwat,C. Kurotjanawong, K. PiyachomkwanK. and OatesC.G. (1999), Cassava starch granule structure function properties: influence of time and conditions at harvest on four cultivars of cassava starch, Carbohydrate Polymers38 (1999), pp. 161-170

[53]. Swinkels J.J.M. (1985). Composition and properties of commercial native starches. Starch/Staerke. 37: 1-5

[54]. Tabacco E, Borreani G, Crovetto GM, Galassi G, Colombo D, Cavallarin L (2006). "Effect of chestnut tannin on fermentation quality, proteolysis, and protein rumen degradability of alfalfa silage". J. Dairy Sci.89 (12): 4736-46.

[55]. Tester, F., Karkalas,J. and Qi. X. (2004). Starch-Composition, fine structure and architecture. J. Cereal Sci. 39:151-165.

[56]. Trubiano P. C. (1987): Succinates and substituted succinate derivatives of starch. In O. B. Wurzburg Modified starches: properties and uses. Pp 131 - 148. Boca Raton, Florida: CRC press

[57]. Veerabahu R.M. and ChinnamadasamyK.(2010).Tropical and Subtropical Agroecosystems, 12: 495- 506

[58]. Wu J.H, Tung Y.T, Chien S.C , Wang S.Y, Kuo Y.H, Shyur L.F, Chang S.T (2008). Effect of Phytocompounds from the Heart-wood of Acaciaconfusaon Inflammatory Mediator Production. J. Agric. Food Chem. 56: 1567-1573. 